\title{
Creative self-fulfillment and goal commitment of teachers at the stage of entering the profession
}

\author{
Lidiya Berngardovna Shneyder ${ }^{1 *}$, Svetlana Vasilyevna Feoktistova ${ }^{2}$, Nadezhda Nikolaevna \\ Vasilyeva $^{2}$, Tatyana Albertovna Golovyatenko ${ }^{3}$, and Elena Viktorovna Usoltseva ${ }^{4}$ \\ ${ }^{1}$ Moscow State University of Education, Institute of Childhood, Department of Psychological \\ Anthropology, Moscow, Russia \\ ${ }^{2}$ Russian New University, Special Defectology Education Department, Moscow, Russia \\ ${ }^{3}$ Russian New University, Psychology and Pedagogy Institute, Moscow, Russia \\ ${ }^{4}$ Russian New University, Institute of Psychology and Pedagogy Special Defectological Education \\ Department, Moscow, Russia
}

\begin{abstract}
Modern education is meant to create conditions for the development and self-development of learners' personalities. This task can only be achieved by teachers who aim for creative professional selffulfillment and self-enhancement; therefore, in the context of global changes the issue of self-design carried out by the subject of teaching activity and development of their personal potential is gaining new significance. The prerequisites for this research are determined by the necessity and possibility for involving young teachers in pedagogic creativity, which helps them to enter the profession successfully. Meanwhile, there are quite a few obstacles to teachers' creative self-fulfillment; at the stage of entering the profession and adaptation to it, there is a gap between the potential and actual action. The objective of this research is to identify the value and conceptual orientation of personality and find out the reasons preventing creative selffulfillment and goal commitment among teachers at the stage of entering the profession. A total of 30 teachers working at Moscow schools ages 25 to 35 took part in the empirical research. Methods: coaching techniques, written survey (empirical questioning), and content analysis of mini-essays. It has been found that creative self-fulfillment is possible if there is a connection between professional devotion, personal success, and clear goal commitment of a teacher. The obstacles on the way to self-fulfillment include a set of unjustified personal restrictions, "hidden" positive ideas of oneself and one's individual abilities, misbalance between personal beliefs and value-conceptual orientations as well as inactivity and exaggeration of external, environmental, or interpersonal barriers. "Reloading" of a teacher is possible if they focus their goals on the future and support such commitment with internal freedom and awareness of their potential and creativity.
\end{abstract}

Keywords: teachers, professionalism, creative self-fulfillment, valueconceptual orientation.

\footnotetext{
*Corresponding author: 1shnejder@yandex.ru
} 


\section{Introduction}

The current socio-economic situation in Russia frequently leads to difficulties in becoming professionals, career progression, and self-fulfillment of specialists at the stage of entering a job and adaptation to it [1-3]. According to D. Super [4], the main goals of this period include getting familiar with career prospects and establishing one's position within the organization and professional community. S. Parkinson believes that the primary goals are accepting the responsibility and accumulation of authority [5]. In our opinion, this is the time of attempts and research, early professionalization, developing competences, and creative adaptation [6]. Even throughout the most ordinary everyday professional activity, regardless of how well a person does their job, there is always an opportunity to do it better. Therefore, there is a gap between the potential of the corresponding person and their actual actions. However, something fills this gap, and understanding what it is can help overcome it [7].

One of the psychological factors that encourage the success of a person's professional growth lies in goal-setting, the level of ambitions, and value-conceptual orientation of the specialist, which serve to expand the boundaries of understanding reality and form future intentions [6, 8-13]. It affects one's attitude towards oneself, colleagues, work, and the world on the whole.

These aspects are of special significance in teaching jobs, where the general "well-being" of the teacher's personality plays a great role; such "well-being" is determined by the selfconcept and includes a set of ideas of oneself, the degree of awareness of one's characteristics, self-esteem, as well as the subjective perception of one's abilities to implement simple and complex intentions.

The effectiveness of activities conducted by a teacher at the early stage of entering the profession, during the time of attempts and research, depends on their professional competence and creative self-fulfillment. In their turn, these aspects depend on the teacher's professional and general culture, value orientations, ideas of the meaning behind their work, and self-perception as a specialist.

Creative self-fulfillment focuses on looking for and selecting new interesting perspectives rather than customary, seemingly safe things. It makes one feel conscious and "alive", i.e. be aware of what one is doing, thinking about, what one values and aims for [7]. Teacher's engagement in pedagogical creative work should be viewed as one of the most significant factors characterizing their professional qualities. Meanwhile, there are quite a few obstacles that prevent teachers' creative self-fulfillment [14-18]. Active creative behavior requires motives, internal aspirations, and values that shape and encourage teacher's goal orientation, which the person is not always aware of.

The objective of this research is to identify the value and conceptual orientation of personality and find out the reasons preventing creative self-fulfillment and internal goal commitment among teachers at the stage of entering the profession.

Specific research methods: a written survey in the form of mini-essays and their further content analysis. Initially, the respondents were offered to use coaching techniques: anecdotes followed by 12 open questions typical for a coaching session, which had to be answered in writing [19].

\section{Organization of the research}

This research was carried out based on the Russian New University in 2019. A total of 30 teachers aged 25 to 35 took part in the research. All the participants were female. 


\section{General characteristics of the obtained results}

The first story "Let there be light!" was about Nasreddin Hodja, who was looking for the keys not where he had lost them but where there was more light. After reading the story, the respondents were asked to write an argumentative essay by answering the given questions. The quantitative breakdown of the answers is represented in Table 1.

Table 1. Breakdown of the answers related to the first story.

\begin{tabular}{|ll|l|}
\hline \multicolumn{2}{|c|}{ Questions to respondents } & \multicolumn{1}{c|}{ Obtained answers (\%) } \\
\hline 1. & What is your goal? What do you pursue? & $\begin{array}{l}\text { Life journey }-66 \% \text {, the highest award - } \\
17 \%, \text { joy }-17 \%\end{array}$ \\
\hline 2. & $\begin{array}{l}\text { Which "key" are you looking for? Which } \\
\text { "door" can it open? }\end{array}$ & $\begin{array}{l}\text { Cognition }-35 \%, \text { harmony }-50 \% ; \\
\text { multifunctionality }-15 \%\end{array}$ \\
\hline 3. $\quad$ Who can help you to find the key? & $\begin{array}{l}\text { Work itself }-66 \%, \text { family }-17 \% \text {; I can find } \\
\text { it myself }-17 \%\end{array}$ \\
\hline 4. $\quad$ What will happen when you find the key? & $100 \%$ - satisfaction \\
\hline
\end{tabular}

Based on the content analysis of the teachers' essays, the general ideas of their answers are the following:

1) the respondents' goals ("highest award", "life journey") are somewhat vague, and they find it difficult to decide what they what from themselves, what prospects and work results they expect;

2) the respondents would like to find a real goal and follow it as much as possible, making necessary efforts and using adequate means of achieving it;

3) the respondents believe that work itself and subjects of the educational environment (experienced teachers, school administration, and students) could help them to find their own way. Five research participants answered that they can solve their problems on their own and all they need is time; another five respondents rely on the support of their family.

4) the respondents think that when they determine their personal goals for themselves and collective goals for their class, it will be easier for them to work and achieve good results, they will treat themselves and their activities with more respect, i.e. they will achieve $100 \%$ satisfaction with their work and themselves.

The second story "Elephants" was about an old elephant living in the zoo who had lost his craving for freedom a long time ago and about a baby elephant who wanted to acquire such freedom.

The quantitative breakdown of the answers is represented in Table 2.

Table 2. Breakdown of the answers related to the second story.

\begin{tabular}{|ll|l|}
\hline \multicolumn{2}{|c|}{ Questions to respondents } & \multicolumn{1}{c|}{ Obtained answers (\%) } \\
\hline $\begin{array}{l}\text { 1. } \\
\text { Who are you more similar to: the } \\
\text { old elephant or the baby elephant? }\end{array}$ & To the baby elephant - 66\%, to the old elephant - 34\% \\
\hline 2. & What can be called your "chain"? & $\begin{array}{l}78 \% \text { - my own fears and uncertainty, 11\% - fatigue, } \\
11 \% \text { - pressure from above }\end{array}$ \\
\hline 3. & What will happen if you get free? & $\begin{array}{l}64 \% \text { - freedom, happiness, 18\% - "release from } \\
\text { captivity", "unloading", 18\% - new goals }\end{array}$ \\
\hline $\begin{array}{l}\text { How could you boost your } \\
\text { motivation for achieving your } \\
\text { goals? }\end{array}$ & $\begin{array}{l}100 \% \text { - miscellaneous responses (enhancing and } \\
\text { developing creative potential, self-organization, } \\
\text { accepting reasonable responsibility, weakening of fears, } \\
\text { building confidence in oneself and one's work results, } \\
\text { looking for professional novelty, etc.). }\end{array}$ \\
\hline
\end{tabular}

Generalized answers given by respondents are as follows:

1) the teachers believe that they are similar to the chained baby elephant because they rush around wanting to do a lot, but their self-imposed "chain" stands in the way; 
2) the respondents think that their "chain" is their fear of unsuccessful attempts to do something or possible disapproval on the side of colleagues, parents, or school administration;

3) the teachers are sure that their "release" will have a positive effect on their work and internal state as they will get more self-confident and find true happiness in teaching;

4) the respondents believe that boosting their motivation for achievement will only be possible after improving their self-esteem, getting rid of the fear of failure, learning to selforganize, etc.

The third story "Hidden gold" is about Buddhist monks, who unexpectedly found an exquisite golden statue of Buddha under a thin layer of plaster, hidden from the others' eyes.

After the respondents wrote their essays, we conducted their content analysis; the quantitative breakdown of the answers is represented in Table 3.

Table 3. Breakdown of the answers related to the third story.

\begin{tabular}{|l|l|}
\hline \multicolumn{1}{|c|}{ Questions to respondents } & \multicolumn{1}{c|}{ Obtained answers (\%) } \\
\hline $\begin{array}{l}\text { 1. Do you consider it possible that there might } \\
\text { be some "golden quality" hidden in you? }\end{array}$ & It is present in everybody - $100 \%$ \\
\hline 2. Why is it hidden from the others' eyes? & $\begin{array}{l}\text { It is meant to be seen only by close people - } \\
89 \% \text {; in order not to dazzle oneself - } 11 \% .\end{array}$ \\
\hline 3. What will happen if it is revealed? & $\begin{array}{l}\text { Social benefit - 64\%, fear of its excessive } \\
\text { usage - 18\%, possibility of harming oneself } \\
\text { due to provoking envy - } 18 \%\end{array}$ \\
\hline $\begin{array}{l}\text { 4. What is necessary to disclose this internal } \\
\text { treasure? }\end{array}$ & $\begin{array}{l}85 \% \text { - self-development, 15\% - asking for } \\
\text { help }\end{array}$ \\
\hline
\end{tabular}

The generalized answers given by respondents are summed up below:

1) the teachers think that each of them possesses a certain "golden quality", which can be used as a resource for their personal and professional growth but is not always explicit;

2) the respondents' "golden qualities are hidden from the others' eyes due to lack of self-confidence, unwillingness to open up in an emotionally uncomfortable environment or because they do not fully realize themselves what their best merit is;

3) if the "golden quality" is identified, the teachers will be able to use it effectively in their personal life and professional activities and, as a result, improve their level of professionalism;

4) to uncover their "internal treasure", the teachers should see and accept it; they are ready to share it with others only if they trust the people surrounding them.

\section{Discussion}

Modern school is meant to create conditions for the development and self-development of learners' personalities. This task can only be achieved by teachers who aim for creative professional self-fulfillment and self-enhancement. If the situation in a certain education institution satisfies the working, cognitive, social, and other needs of a teacher and encourages their creative self-actualization, such a teacher is usually happy with their work, demonstrates strong goal commitment and motivation for boosting their professional activity.

However, this research has shown that despite their potential ability to develop, a teacher can change only when they want it and are ready for it. As a rule, this happens when the teacher identifies the connection between professional service and personal success subjectively perceived and evaluated as such. The obstacles on the way to creative selffulfillment include a set of unjustified personal restrictions, "hidden" positive ideas of oneself and one's individual abilities, misbalance between personal beliefs and value-conceptual orientations as well as inactivity and exaggeration of external, environmental, or 
interpersonal barriers. "Reloading" of a teacher is possible if they focus their goals on the future [20]. Therefore, the very stage of entering the profession is not an obstacle for a creatively thinking teaching team. Surely, the necessity and intention to constantly renew one's skills and make continuous progress can be scary due to general uncertainty and put specialists off by the unpredictability of the distant result. However, those people who do not risk, lose the most by handing over the initiative to other, stronger, people [7].

The problem is that people often try to change the world, their surroundings, or situation by focusing on their unconscious fears and neuroses, while for those who have realized their fears, the matter is easily settled. Such people feel that they are at integral part of this world, perceive its flow, and learn to live a full-fledged life in it by implementing their abilities in multiple ways and fulfill themselves in their activities.

\section{Conclusion}

This research allowed us to identify the goal orientation of a few teachers and the obstacles on this way, sum up the factors that prompt the subjective state of feeling lack of freedom, and actualize self-research of one's own potential. The prospective direction of continuing this scientific quest would be expanding the quantitative, age, and gender composition of the used sample, examination of the obtained results with the help of standardized procedures and methods, and elaborating on the ideas of the effectiveness of pedagogical work at other stages of professional development and career progression.

\section{Acknowledgments}

The publication has been prepared with the support of a grant issued by the Russian Foundation for Basic Research (research project no. 20-013-00654).

\section{References}

1. D.T. Hall, Career development in organization (Jossey-Bas, San-Francisco, 1986)

2. L. Claessens, J. van Tartwijk, H. Pennings, A. van der Want, N. Verloop, P. den Brok, T. Wubbels, Teaching and Teacher Education, 55, 88-99 (2016). https://doi.org/10.1016/j.tate.2015.12.006.

3. M.A. Shchukina, Psikhologia Obucheniya, 5, 60-72 (2015)

4. D.E. Super, The psychology of career (Evanston: Harper \& Row, New York, 1957)

5. S.N. Parkinson, Zakony Parkinsona [Parkinson's laws] (Harvest, Minsk, 2000)

6. L.B. Shneider, Z.S. Akbieva, O.P. Tsaritsentseva, Psikhologiya karery [Career psychology] (Urait, Moscow, 2018)

7. V. Bozhedai, Adaptiruisya ili vymri [Adapt or die out]. Nasha psikhologiya (2016). Accessed on: December 20, 2020. [Online]. Available: https://www.psyh.ru/adaptirujsya-ili-vymri/

8. L.V. Vedernikova, Teoriya i praktika formirovaniya tsennostnykh ustanovok uchitelya na tvorcheskuyu samorealizatsiyu v pedagogicheskoi deyatelnosti: monografiya [Theory and practice of formation of teachers' value orientations towards creative selffulfillment in pedagogical activity: monograph] (Ishim State Pedagogical University named after P.P. Ershov, Ishim, 2012)

9. P. Muchinski, Psikhologiya, professiya, karera [Psychology, profession, career] (Piter, Saint Petersburg, 2004) 
10. S.P. Zueva, Kontsept, 2(18), 16-21 (2013)

11. A.F. Bugaev, Psikhofizika cheloveka. Prakticheskoe rukovodstvo po samorealizatsii [Human psychophysics. Practical guide on self-fulfillment] (Vysshaya shkola, Moscow, 2016)

12. E.V. Fedosenko, Psikhologiya samorealizatsii professionala [Psychology of professional self-fulfillment] (Rech, Moscow, 2016)

13. M.A. Frizen, Psikhologiya samorazvitiya [Psychology of self-development] (Kamchatka State University, Petropavlovsk-Kamchatsky, 2013)

14. L.B. Shneider, Aktualnye problemy psikhologicheskogo znaniya. Teoreticheskie i prakticheskie problemy psikhologii [Actual problems of psychological knowledge. Theoretical and practical problems of psychology], 3(24), 128-147 (2012)

15. G. Ciuladienè, R. Raudeliunaite, Procedia - social and behavioral sciences, 191, 2855-2860 (2015). https://doi.org/10.1016/j.sbspro.2015.04.426.

16. N. Heupt, Training \& Development, 44(6), 16-17 (2017)

17. J.C. Kaufman, J. Cole, Journal of Creative Behavior, 43, 119-134 (2009)

18. R. Reiter-Palmon, E. Robinson-Morral, J.C. Kaufman, J. Santo, Creativity Research Journal, 24, 107-114 (2012)

19. J. Whitmore, Kouching. Osnovnye printsipy i praktiki kouchinga i liderstva [Coaching for Performance: GROWing Human Potential and Purpose - The Principles and Practice of Coaching and Leadership] (Alpina Publisher, Moscow, 2018)

20. K. Stanislavskii, Rabota nad soboi v tvorcheskom protsesse perezhivaniya [Work on oneself in the creative process of experiencing emotions] (Eksmo, Moscow, 2017) 